\title{
基于认知图谱的心理实验标准化测试平台调研
}

孙雨薇 ${ }^{1,2}$, 陈子炜 ${ }^{1,3,4}$, 曹思琪 ${ }^{1,2}$, 齐玥 ${ }^{1,2^{*}}$, 刘勋 ${ }^{1,2^{*}}$

1. 中国科学院心理研究所行为科学重点实验室, 北京 100101 ;

2. 中国科学院大学心理学系, 北京 100049 ;

3. 中国科学院大学中丹学院, 北京 101400 ;

4. 中丹科研教育中心, 北京 101400

*联系人, E-mail: qiy@psych.ac.cn; liux@psych.ac.cn

2020-01-02 收稿, 2020-02-28 修回, 2020-02-28 接受, 2020-03-02 网络版发表

北京市自然科学基金(5184035)和国家重点研发计划(2016YFC0800900)资助

摘要 当前精神障碍的诊断评估主要依赖于心理笁查量表和医生诊断, 而很多精神障碍的临床表现比较复杂, 且 具有相似的外显临床症状，难以依靠现有测量方法从内在机制上进行精准区分. 我们调研了国内外现有的心理实 验测试任务集, 分析并比较现有任务集的特征及优劣势, 发现基于认知图谱构建心理实验标准化测试任务库, 搭建 网络和移动多种施测平台, 有助于采集大规模的心理特征结构化数据. 这些任务可用于构建客观、高效、可靠的 精神障碍量化评估工具、指标和模型, 以期对多重精神障碍进行多维度心理特征的量化评估, 应用于复杂精神障 碍进行精准分类, 服务于精准医疗. 更重要的是, 标准化测试平台也将有助于正常人群认知行为测量, 增强心理测 试的标准性和可比性.

关键词认知行为, 精神障碍, 任务集, 心理实验

20世纪以来，基因、分子生物、脑研究、人工智 能等学科皆蓬勃发展, 但这些先进技术与方法却没有 对临床精神疾病学产生变革式的影响. 当前的精神障 碍诊断体系虽然包含了多种生化、电生理、神经影像 学等检查辅助排除和鉴别诊断 ${ }^{[1 \sim 3]}$, 其本质仍然是以 《国际疾病分类》(International Classification of Diseases, ICD)和《精神障碍诊断与统计手册》(The Diagnostic and Statistical Manual of Mental Disorder, DSM) 为标准, 根据临床症状进行分析的系统 ${ }^{[4]}$. 然而, 精神障 碍的临床症状比较复杂 ${ }^{[5,6]}$, 仅依靠篮查量表和医生诊 断，难以对具有类似表征但不同机制的病症予以精确 区分. 因此，多家机构尝试建立认知神经测试任务集, 通过网络或线下平台呈现心理学实验，量化心理特征 差异, 从而能够在内在机制上区分不同精神障碍. 除了
在精神疾病领域意义重大, 认知行为任务在心理健 康、人才选拔等领域也发挥着作用. 考虑到现有任务 集在测试所属领域划分、施测平台、实验参数设定上 的差异, 标准化测试任务平台在可靠性、规范性与技 术方面上仍然面临着挑战. 鉴于此, 本文拟对现有的国 内外认知心理与行为测试平台进行收集整理，并依据 认知图谱的划分标准, 对这些研究平台分类进行介绍 及梳理, 并对未来发展方向做出展望.

\section{1 认知图谱的定义}

\section{1 认知图谱的概念及产生}

目前, 国内外尚无对认知图谱的确切定义, 通过总 结认知图谱的相关应用及应用场景, 我们将认知图谱 
定义为显示心理概念间关系的结构化图形, 用可视化 技术描述心理过程、心理状态及测试任务, 是构建并 显示概念及它们之间相互联系的工具. 心理过程指在 客观事物作用下，心理活动在一定时间内发生、发展 的过程, 涵盖了认知、情感和意志三类心理活动, 包括 感知觉、记忆、思维、言语、情绪等方面; 心理状态 是心理活动在一定时间内的完整特征，是心理活动展 开的背景 ${ }^{[7]}$. 传统心理测验中心理概念与测试任务是 一对一(或一对多)的映射关系，比如工作记忆可通过即 时再认、N-Back等测试任务测量. 认知图谱拓展了这 种概念与任务关系不完整的组织方式，首次完善了心 理概念与测试任务之间多对多的映射关系，对不同任 务组合测量多种心理功能提供了便利. 比如, 工作记忆 概念的测量对应即时再认、N-Back等任务，其中NBack任务同时对应于工作记忆、认知控制等多个概念.

虽然认知图谱的分类方式在心理学中早有应用, 但“认知图谱”(cognitive atlas)的称呼则是源于2011年斯 坦福大学(Stanford University)心理学教授Russell Poldrack领导的协作性知识构建项目 (http://www.cognitiveatlas.org $/)^{[8]}$. 该研究团队提出, 认知神经科学的前进 需要一种更系统的方法来表示映射到大脑功能的精神 实体, 以及用于操纵和测量心理过程的任务. 认知图谱 中有两种基本的知识: 概念和任务. 其中概念搭建成了 完整的概念网络，从上级概念向下可逐步划分并产生 交互, 例如, 记忆概念包括了工作记忆、来源记忆、情 绪记忆等子概念. 子概念可以从属于多个上级概念, 例 如, 情绪记忆既属于记忆, 又属于情绪. 此外部分子概 念还可以划分出更为精细的下级概念, 同时任务与子 概念相互联系, 每个任务总是至少对应一个子概念, 即 任务可以测量此概念所代表的心理与行为现象.

\section{2 精神疾病领域对认知图谱的推进}

心理学界致力于研发针对精神障碍统一且客观科 学的分类机制, 以不同精神障碍特征的症状为基础进 行鉴别诊断. ICD和DSM两大诊断手册是当前最具权 威的公共卫生、临床诊断和研究应用相关的分类系统. 虽经过多次修订 ${ }^{[9 \sim 11]}$, 但其主要结构缺陷问题仍然存 在 $^{[12]}$ : 精神障碍诊断范式几乎完全依赖于表面的症状 和体征 ${ }^{[13]}$, 在很大程度上与病理和病因学分离. 换言 之, 现有分类系统几乎都是描述性, 而非解释性的 ${ }^{[14]}$, 因此无法高效地探究精神病理学的机制和真正的因果 结构 ${ }^{[15]}$.
基于认知图谱, 整合不同层面正常及异常的心理 表现信息, 可以加深对精神障碍的理解, 为疾病辨别提 供指导性框架; 此外, 根据认知图谱的架构进行精神障 碍诊断, 可以将依赖表面症状的主观判断转变为认知 神经与行为心理综合评估, 认知图谱也为精神障碍精 准鉴别诊断的量化评估工具研发提供了理论依据.

与认知图谱概念网络类似, 美国国立健康研究所 (National Institute of Mental Health, NIMH)提出的基于 研究领域标准(research domain criteria, RDoC)的精神 障碍诊断框架 ${ }^{[16]}$, 同样涵盖了认知图谱的架构. 不同于 $\mathrm{DSM}$ 和ICD根据症状诊断, RDoC将神经科学、行为科 学与精神病学相结合, 试图依据基于神经回路的行为 模型对精神障碍进行分类和诊断 ${ }^{[17]}$. RDoC的新研究框 架包含六大领域和八个结构(图1), 旨在基于可观测的 行为及神经科学的精神障碍症状分类, 为精神病理学 研究提供一个标准化的研究框架, 并最终建立反映神 经和行为科学先进性的精确诊断治疗精神障碍的方法.

\section{2 基于认知图谱的标准化测试平台}

标准化测试平台是适用于多种平台, 具有标准规 范的测试任务集, 把实验设计、数据采集和分析各个 环节按照系统的科学程序组织, 是一个系统化、科学 化、规范化的施测工具. 具体而言, 是根据标准化的实 验指导语、参数设置等完成数据采集, 并输出给定指 标的科学测试工具.

建立基于认知图谱的标准化测试平台将极大地促 进心理实验测试的标准化和规模化. 首先, 对使用人员 的要求降低, 实验任务依据认知图谱进行分类汇总, 只 需知道对应概念即可了解并应用概念相关的一系列实 验范式. 其次, 标准化的实验范式无需主试从零开始编 程, 只需根据平台提供的范式对感兴趣的参数进行修 改即可, 便于任务的推广和大规模采集. 最后, 标准化 测试平台如同一把测量心理特征的“尺子”，增加了心 理实验的可比性. 一方面, 统一了原先同一心理实验范 式的参数, 便于研究间比较, 另一方面整合了同一心理 特征测量的不同范式, 便于围绕同一心理特征进行实 验间比较.

在应用层面，建立基于认知图谱的标准化测试平 台对于推进我国的心理健康状况评估及精神障碍诊断 具有重要意义. 当前精神障碍的诊断评估以及心理健 康水平的评估篮查受限于测量工具, 大多依赖于心理 䇥查量表和医生经验诊断, 但很多精神障碍的临床表 


\begin{tabular}{|c|c|c|c|c|c|c|c|c|}
\hline \multirow[b]{2}{*}{ 领域/构念 } & \multicolumn{7}{|c|}{ 分析单元 } & \multirow[b]{2}{*}{ 实验范式 } \\
\hline & 基因 & 分子 & 细胞 & 通路 & 生理 & 行为 & 自我报告 & \\
\hline \multicolumn{8}{|l|}{ 负性效价系统 } & \\
\hline \multirow{2}{*}{\multicolumn{9}{|c|}{ 急性在威威胁 “胁“恐㥧”) }} \\
\hline 潜在威胁(“焦虑”) & & & & & & & & \\
\hline \multirow{2}{*}{\multicolumn{9}{|c|}{ 持续威胁 }} \\
\hline & & & & & & & & \\
\hline \multicolumn{9}{|l|}{ 无奖赏挫折 } \\
\hline \multicolumn{9}{|l|}{ 正性效价系统 } \\
\hline \multicolumn{9}{|l|}{ 奖赏反应 } \\
\hline \multicolumn{9}{|l|}{$\begin{array}{l}\text { 奖常学习 } \\
\text { 将常评价 }\end{array}$} \\
\hline 奖赏评价 & & & & & & & & \\
\hline \multicolumn{9}{|l|}{ 认知系统 } \\
\hline \multirow{2}{*}{\multicolumn{9}{|c|}{ 注意 }} \\
\hline & & & & & & & & \\
\hline \multicolumn{9}{|l|}{ 规完 } \\
\hline \multicolumn{9}{|l|}{ 言语 } \\
\hline \multicolumn{9}{|l|}{ 认知控制 } \\
\hline \multicolumn{9}{|l|}{ 工作记忆 } \\
\hline \multicolumn{9}{|l|}{ 社会系统 } \\
\hline \multirow{2}{*}{\multicolumn{9}{|c|}{$\begin{array}{l}\text { 归属和依恋 } \\
\text { 社会交往 }\end{array}$}} \\
\hline & & & & & & & & \\
\hline \multicolumn{9}{|l|}{ 自我知觉和理解 } \\
\hline \multicolumn{9}{|l|}{ 他人知觉和理解 } \\
\hline \multicolumn{9}{|l|}{ 唤醒和调节系统 } \\
\hline \multirow{2}{*}{\multicolumn{9}{|c|}{ 唤醒 }} \\
\hline \multirow{2}{*}{\multicolumn{2}{|c|}{$\begin{array}{l}\text { 生物节律 } \\
\text { 睡眠-觉醒 }\end{array}$}} & & & & & & & \\
\hline & & & & & & & & \\
\hline \multicolumn{9}{|l|}{ 感觉运动系统 } \\
\hline \multicolumn{9}{|l|}{ 运动活动 } \\
\hline \multirow{2}{*}{\multicolumn{9}{|c|}{ 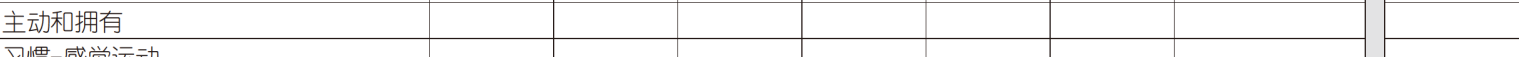 }} \\
\hline & & & & & & & & \\
\hline 先天运动模式 & & & & & & & & \\
\hline
\end{tabular}

图 1 研究领域标准 $(\mathrm{RDoC})$ 矩阵

Figure 1 Research Domain Criteria (RDoC) matrix

现比较复杂, 且具有相似的外显症状 ${ }^{[15]}$, 无法依靠现有 测量方法从内在机制上进行精准区分，因而需开发出 一套用于精神障碍诊疗的客观、高效、可靠的量化评 估工具 ${ }^{[17]}$. 美国国立健康研究所推出的基于认知图谱 的工具包(National Institutes of Health Toolbox, NIH Toolbox), 极大地推进了心理健康状况及精神障碍的诊 断评估 ${ }^{[18]}$. 然而我国尚未有相应的系统化测试工具, 我 们亟须针对中国文化特色及中国人心理健康和精神障 碍研究现状, 开发一个基于认知图谱构建的心理实验 标准化测试平台，从而为我国心理健康及精神障碍的 评估与诊断提供有效工具.

另一方面，目前利用大数据分析进行人工智能的 分类和决策越来越成熟，以其计算力强、精准度高等 优势, 渗透到包括医疗诊断等各个领域 ${ }^{[19]}$. 人工智能辅
助精神障碍的诊疗技术依赖于大规模、标准化、结构 化的数据标注，但当前的心理实验测试在此方面仍较 为欠缺, 因此我们亟须构建一个依赖于开放式、数据 共享和融合的大规模心理实验数据采集平台.

综上，建立基于认知图谱的心理实验标准化测试 平台，能够突破现有心理学实验任务数据采集零散、 分散、方式单一，且无法大规模收集结构化数据的壁 垒. 此外, 这些心理实验任务也可用于采集神经电生理 和神经影像数据, 将认知行为与神经生理相结合 ${ }^{[20]}$, 结 合大数据分析方法和人工智能，有助于心理特征以及 精神障碍量化评估指标和模型的构建，为多维度心理 特征的量化评估和复杂精神障碍的精准分类奠定基础. 这一工具的开发也将切实推进心理学研究成果的交流 比较, 以及心理健康状况的大规模量化评估, 提升研究 
的可重复性, 对了解我国人群的心理健康水平, 并进一 步针对性推进心理健康建设有着重要作用.

\section{3 现有基于认知图谱的神经认知测试任务集}

目前国外已存在一些基于认知图谱的任务平台, 主要针对不同精神障碍而开发. 国内则存在一些传统 的任务测试平台, 主要体现在教学科研以及心理健康 的市场应用上. 以下将从国外、国内已有任务测试平 台两个部分进行介绍.

\section{1 国外任务测试平台介绍}

目前国外以CANTAB、NCANDA、NIH Toolbox 三个任务集为主, 其中CANTAB(http://www.cambridgecognition.com/cantab/)特点是任务精简, 可进行任务组 合测量; NCANDA(http://www.ncanda.org/)的任务主要 针对青少年药物滥用及认知控制功能; NIH Toolbox (http://www.healthmeasures.net/explore-measurementsystems/nih-toolbox)主要特征是适用年龄广, 测量方法 丰富. 3 个任务集的相关研究较为前沿, 同时部分任务 平台可直接进行心理测评.

(i ) CANTAB. CANTAB(Cambridge Neuropsychological Test Automated Battery)为脑研究的多个领域提 供了认知功能的数字测量. 由剑桥大学开发, 力图对神 经网络相关的认知功能进行敏感、准确和客观的测量. CANTAB平台共包括 22 个测验，从属于 6 个领域: 工作 记忆; 学习和执行功能的测试; 视觉、言语和情景记忆; 注意、信息处理和反应时间; 社会和情感识别; 决策和 反应控制. 测试任务可单独进行, 也可组合测量不同治 疗领域的认知功能. 例如, 快速视觉信息处理(rapid visual information processing, RVP)是对持续性注意的敏 感性测试, 测试结果包括反应的准确性、对目标的敏 感性和反应时，可用于阿尔茨海默症、癫㾁、抑郁等 情绪障碍的测量.

目前利用CANTAB平台发表的文章数超过2200篇, 研究证明CANTAB测试对检测神经心理表现的变化非 常敏感 ${ }^{[21 ~ 24]}$. CANTAB的任务都较为精简, 每个任务时 长均不超过 $10 \mathrm{~min}$, 能够灵活组合测量不同认知功能,

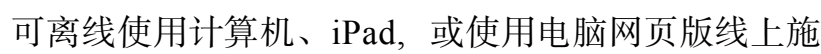
测. 其主要问题是任务数量较少, 仅选取重要领域的代 表性测验; 其次, 对施测设备的限制导致无法在手机、 电脑等不同终端线上线下联合施测，难以大范围采集 数据. （ii ) NCANDA. 美国青少年酒精与神经发育协会 (National Consortium on Alcohol and Neurodevelopment in Adolescence, NCANDA)主要研究酒精对青少年大脑 发育的影响, 以及酒精滥用的脑特征. 其核心任务包括 脑功能和结构像扫描以及以多种认知测试任务 ${ }^{[25]}$, 主 要测量8类认知功能: 抽象、注意、平衡、情绪、情景 记忆、一般能力、工作记忆和运动速度 ${ }^{[26]}$. 其中, 平 衡、一般能力中的任务需要实地操作, 如测量姿势稳 定性的走直线任务, 其他任务皆可在计算机上完成.

该平台主要针对青少年药物滥用及认知控制功能 的测试评估，重点测试反应抑制和奖赏相关实验任务， 并把行为和脑成像相结合. 受NCANDA主旨限制，该 任务集的施测对象集中于12 21岁有酒精使用问题的 青少年. 虽在美国 5 个地方设置实验室便于采集行为与 脑影像数据, 但部分实验无法通过计算机进行标准化 操控，只能在实验现场采集数据(如平衡测试需要在被 试行走过程中测量), 时间成本高, 效率较低.

(iii) NIH Toolbox. NIH工具包是基于便携式可移 动 $\mathrm{iPad}$ 平台开发的心理认知测试，主要针对 $3 \sim 85$ 岁健 康人群和慢性病患者进行 4 个领域的检测, 分别为认 知、运动、感觉功能的测试和自我报告的情绪功能测 量. 除了情绪功能测量主要采用量表, 其他 3 个领域的 实验可在计算机上实现, 每个测验都在 $5 \mathrm{~min}$ 内, 总时 长 $2 \mathrm{~h}$.

NIH工具包适用年龄段广, 测试稳定, 简洁易用. 测 量方法丰富, 适用多种施测场景和群体, 能够无知识产 权限制进行近 5000 人的在线施测，建立了不同年龄常 模. 主要问题同样是平台单一, 无法在不同平台联合 使用.

\section{2 国内任务测试平台介绍}

与国外平台针对精神疾病领域, 以及根据认知图 谱划分任务不同，目前国内已经建设完成的测试平台 主要是依据心理学学科分类或面向某一类特定用户需 求建设, 平台的类别可以概括为三类, 即实验教学类、 市场应用类和科研类(表1).

(i ) 实验教学类测试平台. 实验教学类平台主要 包括了京师博仁、心灵方舟、辅仁淑凡 3 个测评系统. 京师博仁PsychELab心理学综合实验设计系统主要用 于心理实验教学和研究, 包括认知、普通心理学(普 心)、教育与发展、工程、人机交互等心理学实验. 实 验程序均可以在默认实验的基础上，自主设置实验参 
表 1 国内现有认知任务测评系统

Table 1 Domestic existing cognitive task assessment system

\begin{tabular}{|c|c|c|}
\hline & 名称 & 网址 \\
\hline \multirow{3}{*}{ 实验教学类 } & 京师博仁PsychELab心理学综合实验设计系统 & http://xlcp.jingshiboren.com/xinlishiyanruanjian/ \\
\hline & 心灵方舟DPES可设计心理实验系统(Psykey) & https://www.xlfz.cn/index/index.html \\
\hline & 辅仁淑凡大学生心理学实验设计系统 & http://www.shufan.net/Product/ProductDetail?ID=13 \\
\hline \multirow{3}{*}{ 市场应用类 } & 上海北辰心理测评软件 & http://www.bcxl.com.cn/ \\
\hline & 北森测评 & https://www.beisen.com/ \\
\hline & 北京心海导航 & https://www.xinhaisoft.com/index.html \\
\hline \multirow{2}{*}{ 科研类 } & 中国科学院心理研究所云端心理实验室 & http://www.cpsylab.com/ \\
\hline & CLIMB儿童认知发展任务集 & https://climbgroup.org/, 筹备中 \\
\hline
\end{tabular}

数, 更换实验材料. 心灵方舟DPES可设计心理实验系 统(Psykey), 分为普心、儿童、基本心理能力、认知和 经典心理学实验五部分. 借助云技术、大数据、移动 互联等构建了心理教育云平台. 辅仁淑凡大学生心理 学实验设计系统涵盖约 150 个实验, 包含经典研究范式 和国内外实验心理学最新研究成果, 实验设置灵活, 能 进行全面的心理学实验教学和研究.

实验教学类任务平台的使用者可以根据自身情况， 对实验材料进行适度地修改. 但系统并未根据认知图 谱进行设计, 且主要针对从事心理实验工作的人员, 受 众较窄. 同时由于数据为线下采集, 且需要购买安装任 务系统, 使得该平台无法进行大范围数据采集任务.

(ii) 市场应用类测试平台. 市场应用类平台主要 包括了上海北辰、北森、北京心海导航 3 个测评系统. 上海北辰心理测评软件的注意力变量测试系统(test of variables of attention, TOVA) 属于持续性操作测验(continuous performance test, CPT), 用于对注意力缺陷(多 动)障碍( $\mathrm{ADD} / \mathrm{ADHD}$ )进行诊断和疗效判定, 可提供儿 童和成年人注意力、冲动控制能力诊断及疗效评价. 此产品是收费系统, 需购买反应盒或在机构测试. 北森 能力倾向计算机自适应测验CATA(computerized adaptive test for ability)使用在线标定技术和策略抽题, 用 于大规模招聘中对认知能力的快速判断. 测验涉及言 语能力、逻辑推理、空间能力和数学能力 4 个维度. 北 京心海导航的认知能力训练分析系统, 通过脑电分析 及反馈训练, 对认知能力进行测评, 并根据结果生成认 知训练游戏. 系统中包含信息加工、注意、空间认 知、记忆、情绪和问题解决六大认知能力.

市场应用类任务平台的特点是应用性强，能够针 对相应领域进行精细测评. 部分平台依照认知图谱归
类, 但涵盖范围不全面, 未考虑心理概念之间的结构关 系, 只纳人目标用户需求的相关任务. 该类任务平台因 其商用价值, 实验材料和参数无法更改, 需购买其服务, 无法实现跨平台实验研究及大规模数据采集.

(iii) 科研类测试平台. 科研类平台主要包括了云 心实验室、CLIMB(建设中)两个测评系统. 中国科学 院心理研究所云端心理实验室(Cloud Psychology Lab, CPsylab)于2013年创立，在线提供多种内隐和外显测 验, 测验结束即时呈现被试占比结果及解释. 正在建设 中的CLIMB 儿童认知发展任务集为中国科学院心理研 究所脑与心智毕生创新研究中心项目, 将以认知图谱 为依托, 涵盖动作、注意、执行功能、知觉、记忆、 决策、言语、社会认知和情绪等领域 23 个任务, 任务 时长约在3 15 min.

云心实验室属于在线开放式平台，可在线作答并 呈现结果解释，但任务涉及广度非常有限. CLIMB涵 盖认知发展多领域，但部分肢体协调任务仍需要现场 测验, 对主试要求高, 难以线上收集数据. 此类任务平 台可应用于旨在科研的实验中, 但效率较低, 无法实现 标准化的大规模跨平台实验.

\section{3 国内外任务测试平台发展比较}

国外有多个任务平台基于认知图谱建设，但任务 覆盖面不够广泛，没有完整的概念-任务体系. 国内测 试平台多只侧重某部分的测试(如问卷或认知任务), 虽 然一些测试平台上的实验范式较为全面，却不能满足 跨平台大规模施测的要求，而是以教学模式为主. 并 且，国内外统一的局限在于这些平台都只关注自身感 兴趣的部分, 只能算认知图谱平台的维形. 因此, 在我 国建立一个基于认知图谱、多终端的标准化实验测试 
平台将能满足完善心理实验体系，进行大规模、高效 数据采集的需求.

\section{4 总结与展望}

随着大数据时代来临，传统心理测验的可靠性、 规范性与技术方面都面临挑战, 同时也面临着机遇. 建 立一个心理实验的标准化开放性测试平台, 对未来大 规模数据采集尤为重要, 这将有利于心理学实验的便 捷化、标准化、灵活化、经济化和高效化.

现有任务集的主要问题是任务平台单一，限制了 任务的适用情境及范围, 导致用户面较窄, 不便于大规 模数据收集. 如NIH工具箱适用于 $i P a d, ~ N C A N D A$ 测试 需要电脑, 其中部分测试需要现场完成, 国内的几个实 验教学系统更是需要在离线系统中施测. 一些传统任 务平台的实验参数调整受限, 应用场景也局限于教 学、演示. 传统测试任务大多为单一测量, 没有统一标 准, 难以对不同研究的范式进行比较. 基于认知图谱的 标准化测试平台, 则有机结合了心理概念和测试任务, 对测试任务进行标准化, 且能够实现跨平台的便捷化 施测. 基于认知图谱架构的标准化任务, 测验人员能够 迅速找到与概念对应的任务且无需编程直接使用, 一 方面有利于构建心理实验的标准化测量工具, 增加实 验间的可比性; 另一方面有利于在心理学非专业人士 中的推广, 节约人员和时间成本. 最后, 针对不同心理
特征和精神障碍, 平台中的任务能够进行组合测量, 极 大增加了心理测验的灵活性.

未来应着力基于认知图谱, 构建心理实验的标准 化测试任务, 搭建涵盖网络和移动端的跨平台标准化 任务库, 以便采集大规模心理特征结构化数据, 进而了 解和评估我国人群的心理健康水平, 推进国民心理健 康建设. 基于认知图谱的标准化测试平台, 应当涵盖测 试任务、系统设计及平台应用等层面. 首先, 对于测试 任务而言, 平台需根据认知图谱构建, 囊括动作、注 意、执行认知控制、知觉、记忆、动机、情绪、推理 决策、学习、语言及社会功能等各方面. 其次, 在系统 设计上, 因大数据、开源、标准化等特征, 平台的系统 应当考虑到任务开发平台、服务系统层以及终端等方 面. 从Python、HTML5、JavaScript等开源系统搭建, 到 平台任务的标准化审核, 再到终端施测数据回传等细 节都需要考量. 最后, 建立包括计算机及手机移动端的 跨平台施测, 将极大扩展任务库的适用及施测范围, 满 足不同对象和场景的需求, 如科研、教育机构、医院 以及个人和家庭.

面对大数据潮流及心理健康领域的发展, 国外许 多研究人员尝试建立基于认知图谱的任务平台, 我国 的心理学者们也当行动起来, 建立适用于我国的标准 化测试平台, 为我国心理健康评估诊断和心理实验数 据采集带来新的进步.

\section{参考文献}

1 Liu J. Diagnosis and assessment of children with autism (in Chinese). Chin J Pract Pediatr, 2008, 23: 167-170 [刘靖. 儿童孤独症的诊断和评估. 中国实用儿科杂志, 2008, 23: 167-170]

2 Liu J, Li S R, Zhang W X, et al. Assessment of Computerized Diagnostic System of Geriatric Mental State Schedule Shortened Community Version (GMSA-AGECAT) (in Chinese). Chin Ment Heal J, 2001, 4: 220-222 [刘津, 李淑然, 张维熙, 等. 老年精神状况量表社区简版计算机诊 断系统(GMSA-AGECAT)在中国的初步测试. 中国心理卫生杂志, 2001, 4: 220-222]

3 Zou X B, Deng H Z. Expounding on the diagnosis criteria of autistic spectrum disorders of Diagnostic and Statistical Manual of Mental Disordersfifth edition, DSM-V (in Chinese). Chin J Pract Pediatr, 2013, 28: 561-563 [邹小兵, 邓红珠. 美国精神障碍诊断分类手册第5版“孤独症谱系障 碍诊断标准”解读. 中国实用儿科杂志, 2013, 28: 561-563]

4 Guo T S, Luo X L, Li X C, et al. Reliability and validity of clinical assessment of expert diagnosis system for mental disorder (in Chinese). Chin J Clin Psychol, 2014, 22: 96-100 [郭田生, 骆晓林, 李新纯, 等. 心理疾病专家诊断系统的临床信度和效度评价. 中国临床心理学杂志, 2014, 22: 96-100]

5 Bartels S J, Xiang D Z. Differential diagnosis of depressive symptoms of schizophrenia (in Chinese). Foreign Med Sci (Sect Psychiatry), 1989, 2: 104-107 [Bartels S J, 向德昭. 精神分裂症抑有症状的鉴别诊断. 国外医学精神病学分册, 1989, 2: 104-107]

6 Yuan Y G, Wu A Q, Zhang X B. Talking about the diagnosis of comorbidity from the relationship between anxiety and depression (in Chinese). Foreign Med Sci (Sect Psychiatry), 2001, 1: 17-19 [袁勇贵, 吴爱琴, 张心保. 从焦虑和抑郁的关系谈共病的诊断. 国外医学精神病学分册, 2001, 1: 17-19]

7 Lin C D, Yang Z L, Huang X T. The Comprehensive Dictionary of Psychology (in Chinese). Shanghai: Shanghai Education Publishing House, 2003. 1392 [林崇德, 杨治良, 黄希庭. 心理学大辞典. 上海: 上海教育出版社, 2003. 1392]

8 Poldrack R A, Kittur A, Kalar D, et al. The Cognitive Atlas: Toward a knowledge foundation for cognitive neuroscience. Fron Neuroinform, 2011, 


\section{5: 17}

9 Khoury B, Kogan C, Daouk S. International classification of diseases 11th edition (ICD-11). In: Zeigler-Hill V, Shackelford T, eds. Encyclopedia of Personality and Individual Differences. Cham: Springer, 2017. 1-6

10 American Psychiatric Association. Diagnostic and Statistical Manual of Mental Disorders. Arlington: American Psychiatric Association, 2013

11 American Psychiatric Association. Diagnostic and Statistical Manual of Mental Disorders: DSM-III. Washington DC: American Psychiatric Association, 1980

12 Frances A. RDoC is necessary, but very oversold. World Psychiatry, 2014, 13: 47-49

13 Clark L A, Cuthbert B, Lewis-Fernández R, et al. Three approaches to understanding and classifying mental disorder: ICD-11, DSM-5, and the National Institute of Mental Health's Research Domain Criteria (RDoC). Psychol Sci Public Interest, 2017, 18: 72-145

14 Guze S B. The perspectives of Psychiatry. 2nd ed. Am J Psychiat, 2000, 157: 141

15 Cuthbert B N. The Research Domain Criteria (RDoC): An analysis of methodological and conceptual challenges. Behav Res Ther, 2014, 62: 140142

16 Insel T, Cuthbert B, Garvey M, et al. Research Domain Criteria (RDoC): Toward a new classification framework for research on mental disorders. Am J Psychiat, 2010, 167: 748-751

17 Cuthbert B N. The RDoC framework: Facilitating transition from ICD/DSM to dimensional approaches that integrate neuroscience and psychopathology. World Psychiatry, 2014, 13: 28-35

18 Casey B J, Oliveri M E, Insel T. A neurodevelopmental perspective on the Research Domain Criteria (RDoC) Framework. Biol Psychiatry, 2014, 76: $350-353$

19 Insel T R. The NIMH Research Domain Criteria (RDoC) Project: Precision medicine for psychiatry. Am J Psychiat, 2014, 171: 395-397

20 Gershon R C, Cella D, Fox N A, et al. Assessment of neurological and behavioural function: The NIH Toolbox. Lancet Neurol, 2010, 9: 138-139

21 Bezuch N E, Bradburn S, Sipilä S, et al. Association of interleukin-6 rs 1800796 polymorphism with reduced cognitive performance in healthy older adults. Meta Gene, 2019, 19: 51-55

22 Sahakian B J, Owen A M. Computerized assessment in neuropsychiatry using CANTAB: Discussion paper. J Roy Soc Med, 1992, 85: 399-402

23 De Luca C R, Wood S J, Anderson V, et al. Normative data from the CANTAB. I: Development of executive function over the lifespan. J Clin Exp Neuropsychol, 2003, 25: 242-254

24 Robbins T W, James M, Owen A M, et al. Cambridge Neuropsychological Test Automated Battery (CANTAB): A factor analytic study of a large sample of normal elderly volunteers. Dementia, 1994, 5: 266-281

25 Johnston L D, O’Malley P M, Bachman J G, et al. Monitoring the future: National results on adolescent drug use. In: Overview of Key Findings, 2008. National Institutes of Health, 2014, 1: 85

26 Sullivan E V, Brumback T, Tapert S F, et al. Cognitive, emotion control, and motor performance of adolescents in the NCANDA study: Contributions from alcohol consumption, age, sex, ethnicity, and family history of addiction. Neuropsychology, 2016, 30: 449-473 


\title{
Survey on standardized testing platform of psychological experiment based on Cognitive Atlas
}

\author{
Yuwei Sun ${ }^{1,2}$, Ziwei Chen ${ }^{1,3,4}$, Siqi Cao ${ }^{1,2}$, Yue Qi ${ }^{1,2^{*}} \&$ Xun Liu ${ }^{1,2^{*}}$ \\ ${ }^{1}$ Key Laboratory of Behavioral Science, Institute of Psychology, Chinese Academy of Sciences, Beijing 100101, China; \\ ${ }^{2}$ Department of Psychology, University of Chinese Academy of Sciences, Beijing 100049, China; \\ ${ }^{3}$ Sino-Danish College, University of Chinese Academy of Sciences, Beijing 101400, China; \\ ${ }^{4}$ Sino-Danish Center for Education and Research, Beijing 101400, China \\ * Corresponding authors, E-mail: liux@psych.ac.cn; qiy@psych.ac.cn
}

The current diagnostic assessment of mental illness mainly relies on psychological scales and the subjective judgment of doctors, and the clinical manifestations of many types of mental disorders are complex but very similar in the clinical symptoms, which cannot be accurately distinguished from the internal mechanism by existing measurement methods. At present, big data analysis has penetrated into various fields including medical diagnosis. These techniques rely on large amounts of structured annotated data and are currently lacking in psychometric testing. In recent years, the National Institutes of Health has proposed a diagnostic framework for mental illness based on Research Domain Criteria (RDoC), which attempts to differentiate mental disorders by internal mechanisms based on a large number of observable behavioral and neuroscientific indicators. The framework of the Cognitive Atlas is embodied in the RDoC. Cognitive Atlas is a tool for constructing and displaying interconnections between mental concepts and mental processes, mental states, and testing tasks. The standardized testing platform of psychological experiments based on Cognitive Atlas can break through the barriers of scattered data collection of psychological experiment task, single method and inability to collect structured data in large scale. In addition, it plays an important role in promoting the communication and comparison of psychological research results, improving the repeatability of research, understanding the national mental health level, and further promoting the construction of mental health. We investigated the task batteries that applied at home and abroad, and found that the representative task platforms abroad, such as CANTAB, NCANDA, and NIH Toolbox, were mainly developed for different mental diseases, while there are some traditional task testing platforms in China, mainly embodied in teaching, scientific research and the market application of mental health. We analyzed and compared the characteristics, advantages and disadvantages of the existing set of tasks, and concluded that foreign task platforms are mostly based on Cognitive Atlas construction, but the task coverage is not extensive enough, and there is no complete concept-task system. Most domestic test platforms only focus on some part of the test (such as questionnaires or cognitive tasks). Although the experimental paradigm on some test platforms is relatively comprehensive, it cannot meet the requirements of crossplatform large-scale testing, but mainly focuses on teaching mode. Moreover, the limitation of unity at home and abroad is that these platforms only focus on the part they are interested in, which is only the prototype of the Cognitive Atlas platform. Therefore, the establishment of a standardized experimental testing platform based on Cognitive Atlas and multiple terminals in China will meet the needs of improving the psychological experiment system and carrying out largescale and efficient structured data of psychological characteristics collection. Combined with these tasks and big data, we can construct the objective, efficient and reliable quantitative assessment tools, indicators and models for mental diseases, so as to carry out quantitative evaluation of multi-dimensional psychological characteristics of multiple mental disorders, apply them to accurate classification of complex mental diseases and serve precise medicine. More importantly, the standardized test platform will also contribute to the measurement of cognitive behavior of normal people and enhance the standardization and comparability of psychological tests.

cognitive behavior, mental disorder, task platform, psychological experiment

doi: 10.1360/TB-2020-0004 